\title{
MONITORING THE SECONDARY FOREST SUCCESSION AND LAND COVER/USE CHANGES OF THE BŁĘDÓW DESERT (POLAND) USING GEOSPATIAL ANALYSES
}

\author{
Marta Szostak, Piotr WężyK, Pawe€ Hawryło, Marta Puchąa \\ Institute of Forest Resources Management, University of Agriculture in Krakow, Poland
}

Manuscript received: November 27, 2015

Revised version: May 23, 2016

\begin{abstract}
Szostak M., WężYK P., Hawryło P., Puchaza M., 2016. Monitoring the secondary forest succession and land cover/use changes of the Błędów Desert (Poland) using geospatial analyses. Quaestiones Geographicae 35(3), Bogucki Wydawnictwo Naukowe, Poznań, pp. 5-13, 5 figs, 1 table.

ABSTRACT: The role of image classification based on multi-source, multi-temporal and multi-resolution remote sensed data is on the rise in the environmental studies due to the availability of new satellite sensors, easier access to aerial orthoimages and the automation of image analysis algorithms. The remote sensing technology provides accurate information on the spatial and temporal distribution of land use and land cover (LULC) classes. The presented study focuses on LULC change dynamics (especially secondary forest succession) that occurred between 1974 and 2010 in the Błędów Desert (an area of approx. 1210 ha; a unique refuge habitat - NATURA 2000; South Poland). The methods included: photointerpretation and on-screen digitalization of KH-9 CORONA (1974), aerial orthoimages (2009) and satellite images (LANDSAT $7 \mathrm{ETM}^{+}, 1999$ and BlackBridge - RapidEye, 2010) and GIS spatial analyses. The results of the study have confirmed the high dynamic of the overgrowth process of the Blędów Desert by secondary forest and shrub vegetation. The bare soils covered $19.3 \%$ of the desert area in 1974, the initial vegetation and bush correspondingly $23.1 \%$ and $30.5 \%$. In the years $2009 / 2010$ the mentioned classes contained: the bare soils approx. $1.1 \%$, the initial vegetation $-8.7 \%$ and bush $-15.8 \%$. The performed classifications and GIS analyses confirmed a continuous increase in the area covered by forests, from $11.6 \%$ (KH-9) up to $24.2 \%$, about 25 years later (LANDSAT 7) and in the following 11 years, has shown an increase up to $35.7 \%$ (RapidEye 2010).
\end{abstract}

KEYwORDs: LULC changes; Geographic Object Based Image Analysis (GEOBIA); pixel-based classification, GIS analyses; secondary forest succession

Corresponding author: Marta Szostak (e-mail: m.szostak@ur.krakow.pl)

\section{Introduction}

Geoinformation (GI) technologies based on updated spatial geodata (especially using remote sensing imaging) and state of the art technical solutions (software, hardware, the internet, etc.) provide comprehensive and objective information for environmental studies. The use of high-resolution true color and false color (VNIR) RGB composite aerial photos (also stereoscopic solutions) and multispectral satellite images, has become much easier during the last few decades. A multitude of environmental research has confirmed the possibility of using this geodata supported by GIS analyses for remote and automated environment monitoring in the area of nature protection, forestry, meteorology, climatology and hydrology (Coops, White 2003, Corona et al. 2008, Drzewiecki et al. 2014, Latifi, Galos 2010, Wężyk et al. 2013). The role played by image 
classification based on multi-source, multi-resolution and multi-temporal remote sensed data is ever increasing in the environmental studies field. The geoinformation technologies based on such data from various sources (remote sensed, ground truth campaigns, and existing databases) are finding particular applications as they allow for a multilateral approach to the issue of researching the transformations of land use and land cover (LULC) especially the process of forest succession. These transformations resulting in landscape changes are very common and result from a combination of natural and anthropogenic factors. The analyses of the dynamics and the directions of LULC changes are a significant element of sustainable space management. However, this process is difficult and requires appropriate cartographic materials, which have to undergo complex processing. The integration of digital photogrammetry and remote sensing along with other technologies, such as GIS, LiDAR and GNSS can be applied, for instance, in the determination of different types of LULC classes or in characterizing the vertical structure of vegetation (Bork, Su 2007, Singh et al. 2012). Through the use of aerial and satellite images, which are an objective reflection of the image of the Earth in very high quality, it is possible to isolate the different LULC classes, even those occupying relatively small areas.

The topic of this paper concerns an assessment of the process of monitoring LULC changes based on multi-temporal aerial and satellite images and GIS spatial analyses. This paper presents an application of GI technologies (photointerpretation and on-screen vectorization) used for the determining of LULC changes in particular the stage and direction of secondary forest succession, which is ongoing in an extremely rare, dry terrestrial European ecosystem - the Błędów Desert. The automated determination of LULC classes was also tested. An attempt to automate this process was done by use of Geographic Object Based Image Analysis (GEOBIA), integrated with the spatial analyses in GIS. GEOBIA was selected for the study because this type of image classification is mainly used in the world's leading research centers involved in the processing of remote sensing images (de Kok, Wężyk 2008, Blaschke 2010). GEOBIA technology uses both: the traditional approach of pixel classification, as well as the logical connections and the geometry of the groups of pixels (objects) having specific forms (elements of texture). Using the multi-temporal satellite and aerial images allows the GEOBIA processing (eCognition; TRIMBLE GeoSpatial) to significantly enhance the process of image interpretation and to diminish the subjectivity of the operator. The crucial characteristic of GEOBIA is that instead of analyzing single pixels, the method uses segments (objects) that more properly represent real world entities (Baatz, Schape 2000). In an object-based classification workflow, many different features such as: brightness, shape, texture and context information are taken into consideration (Blaschke 2010, Hay, Castilla 2006). Hay and Castilla (2008) defined GEOBIA as a sub-discipline of Geographic Information Science (GIScience) focused on the development of automated methods of dividing remote sensing imagery into meaningful image-objects, and assessing their characteristics using spatial, spectral and temporal scales, thus generating new geographical information in a GIS-ready format. Recently, Blaschke et al. (2014) based on the previous studies (Blaschke 2010, Hay, Castilla 2006, 2008) recognized GEOBIA as a new paradigm for remote sensing and GIScience. Baatz et al. (2008) distinguished two types of GEOBIA classification: an object-based classification approach and a more advanced object-oriented approach.

The main goal of the presented paper is to identify opportunities where the automatic approach object-based image analyses, when assessing land use/cover changes. The problem was to define the possibilities for detecting vegetation classes in an automatic way with using GIS analysis and OBIA tools compared to traditionally applied photointerpretation and on-screen vectorization methods, but in a more objective and efficient way. The topic of the article refers to the assessment of the process of changes in the land cover (land use), mainly including secondary forest succession based on multi-temporal aerial and satellite images.

\section{Material and methods}

The study area - an area of the Błędów Desert (the analyzed area: approx.: $1210.5 \mathrm{ha}$ ) - is located in Southern Poland (Fig. 1), in the Dolnoslaskie and Malopolskie Provinces (WGS 84: $50^{\circ} 21^{\prime} \mathrm{N}$; 

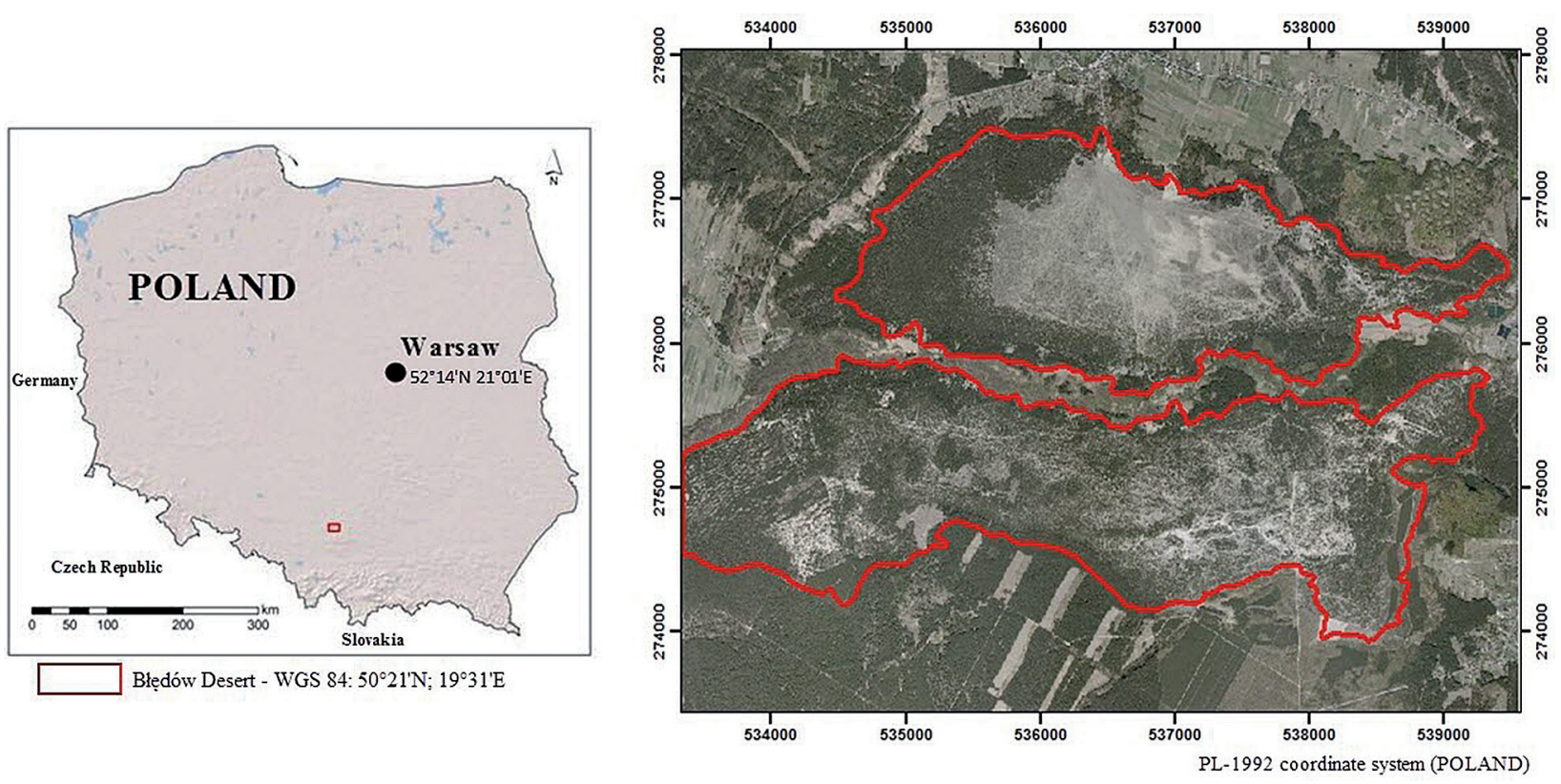

Fig. 1. The area under study (left - red rectangle; right - the enlarged area).

19³1'E). The Błędów Desert is a refuge habitat, which has been protected within the NATURA 2000 European Network since 2007 (PLH 120014). It is considered a great peculiarity of nature not only in Poland, but also abroad. The Desert ("The Polish Sahara") is the greatest in Europe, and the biggest area of quicksand in Poland. It is naturally and geographically unique, because it was formed in a moderate and humid climate and the landscape there, is very specific. At the beginning of the $19^{\text {th }}$ century, the Błędów Desert covered an area of more than 8000 ha. Today, this ecosystem is only 3200 ha and about one third of it is made up of regions of sandy bare soils. The area of the Błędów Desert is also a territory of the UE Life+ project, aimed at achieving the protection of the largest complex of sandy habitats in Poland. The goal of this project is the preservation of the remaining areas of inland sandy dunes that have interesting morphological forms including numerous rare and legally protected species of fauna and flora. Recently, many protective activities are being carried out on the Błędów Desert with the goal of re-covering and preserving the biodiversity of the very rare European terrestrial ecosystem.

The research defines the nature and dynamics of the spatio-temporal LULC changes (1974-2010) of the Błędów Desert area with the application of photointerpretation with on-screen digitization of aerial and satellite images and GIS spatial analyses. These methods are universal and are currently the widely used in environmental studies. Archival and current photogrammetrical and remote sensing data has been used to define the occurring transformations, mainly the progress of secondary forest succession. The following remote sensing data and cartographic materials were applied:

- digital aerial orthoimages, true color RGB composite (GSD $0.25 \mathrm{~m}, 2009$ )

- satellite images:

- archival KH-9 CORONA (GSD 6-9 m, 1974)

- LANDSAT 7 ETM+ (GSD 28.5 m MS / 15.0 m PAN, 1999)

- BlackBridge RapidEye (GSD 5.0 m, 2010)

- GIS vector cadastral data (parcels + land use classes; access via GEOPORTAL).

The purpose of using manual on-screen vectorization was to determine the areas affected by the secondary succession of forest vegetation using the traditional means of the photointerpretation of airborne and satellite images (1974-2010). This step was carried out in ArcGIS (Esri) environment. Various GI methods of data input and processing were used in this study, e.g.: image georeferencing into the PL-1992 coordinate system (POLAND), photointerpretation with onscreen vectorization and GIS spatial analyses. The operator vectorized high vegetation as the outlines of groups of trees, bearing in mind that in images an improper situation (shifting) of the 


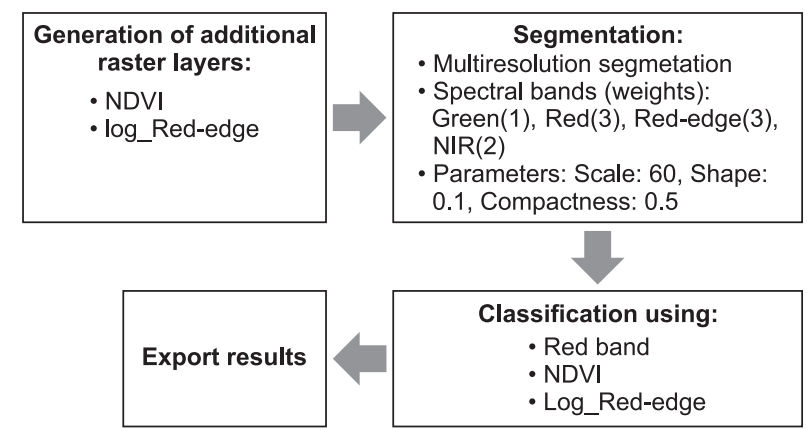

Fig. 2. The flow chart of the GEographic Object Based Image Analysis (GEOBIA).

tops of high trees can occur (depending on the distance from the main point in the image).

This paper presents also an application of GI technologies in identify opportunities an automated determination of LULC classes. Pixelbased classification and GEOBIA approach was tested based on the BlackBridge (RapidEye, 2010) data. Supervised pixel-based classification was carried out using ENVI (Exelis) software using the minimal distance algorithm (an assessment of the results with an application of test fields - an error matrix). The resulting raster was subjected to filtration (median filter), and then a conversion to a vector model was performed. After this step, an intersection with the desert borders was made. A further task required an object-based classification using eCogniton (TRIMBLE GeoSpatial). The work-flow of the GEOBIA approach is presented below (Fig. 2).

The GEOBIA method can be generally considered as a two-stage process of segmentation and then the classification of the resulting segments. To cope with more demanding classification requirements, the object-oriented approach can be applied (Baatz et al. 2008, Benz et al. 2004, Willhauck et al. 2000). In the presented study, the eCognition Developer (Trimble GeoSpatial) software was used to perform a rule-based classification. Thanks to the usage of a modular programming language - The Cognition Network Language (CNL), the software allowed for the very flexible and efficient design of the rule-based classification workflow.

\section{Results}

The studies of airborne and satellite images (photointerpretation and on-screen vectorization) of the vegetation and land cover classes of the Błędów Desert have been carried out: 1974, 1999, 2009/2010 (Fig. 3) and have confirmed the highly dynamic process of the overgrowing of the Błędów Desert from the following stages: initial vegetation, bush and single trees and secondary forest succession (Table 1, Fig. 4). Bush was the dominated LULC class in the past (1974), covered $30.5 \%$ of the Błędów Desert area. The initial vegetation and bare soil covered correspondingly $23.1 \%$ and $19.3 \%$ of the study area. The area of coniferous forests was lower at the level of approx. $10.4 \%$, deciduous forest $1.2 \%$ and sparse forest $15.5 \%$ of the Błędów Desert area. About 25 years later (LANDSAT 7) bush covered $32.9 \%$, initial vegetation $22.5 \%$ and bare soil only $3.2 \%$ (coniferous forests $21.3 \%$, deciduous forest $2.9 \%$, sparse forest $17.1 \%$ of the study area). In the years 2009/2010 these analyzed LULC classes decreased (manual vectorization): bare soils to $1.1 \%$ ( $-18.2 \%$ changes in period of time: 1974-2010), initial vegetation to $8.7 \%(-14.4 \%)$ and bush to $15.8 \%(-14.7 \%)$ of the study area. GIS spatial analyses confirmed a continuous increase of forest areas (coniferous forest + deciduous forest), from $11.6 \%$ (KH-9, 1974) up to $24.2 \%$ (LANDSAT TM 7, 1999) - increment of $12.6 \%$ in period of time: $1974-1999$. The on-screen digitalization of the aerial orthoimages (2009) simultaneously with the BlackBridge (RapidEye, 2010) has shown increase in forests also, up to $35.7 \%$ of the analyzed area (increment of $11.5 \%$ in period of time: $1999-2010$ and $24.1 \%$ in period of time: 1974-2010). Sparse forest area was changed from $15.5 \%$ (1974), $17.1 \%$ (1999) to $38.7 \%$ (2009/2010) of the Błędów Desert.

Automated determination of LULC classes was carried out satisfactory. The example of GEOBIA analysis steps and results are presented below (Fig. 5).

The result of the photointerpretation and onscreen vectorization (based simultaneously on BlackBridge - RapidEye, 2010 and aerial orthoimages, 2009) the pixel-based classification and the GEOBIA approach (based also on BlackBridge - RapidEye, 2010) were very similar compared to the assigned classes and the area of the distinguished objects. GEOBIA approach shows forest class as $36.9 \%$ (25.3\% - an increase in period of time: 1974-2010). Usage of the pixel-based classification approach resulted in the largest forest area at the level of $40.2 \%$ (an increase of $28.6 \%$ ). A small difference $(1.2 \%)$ that exists between the results in 

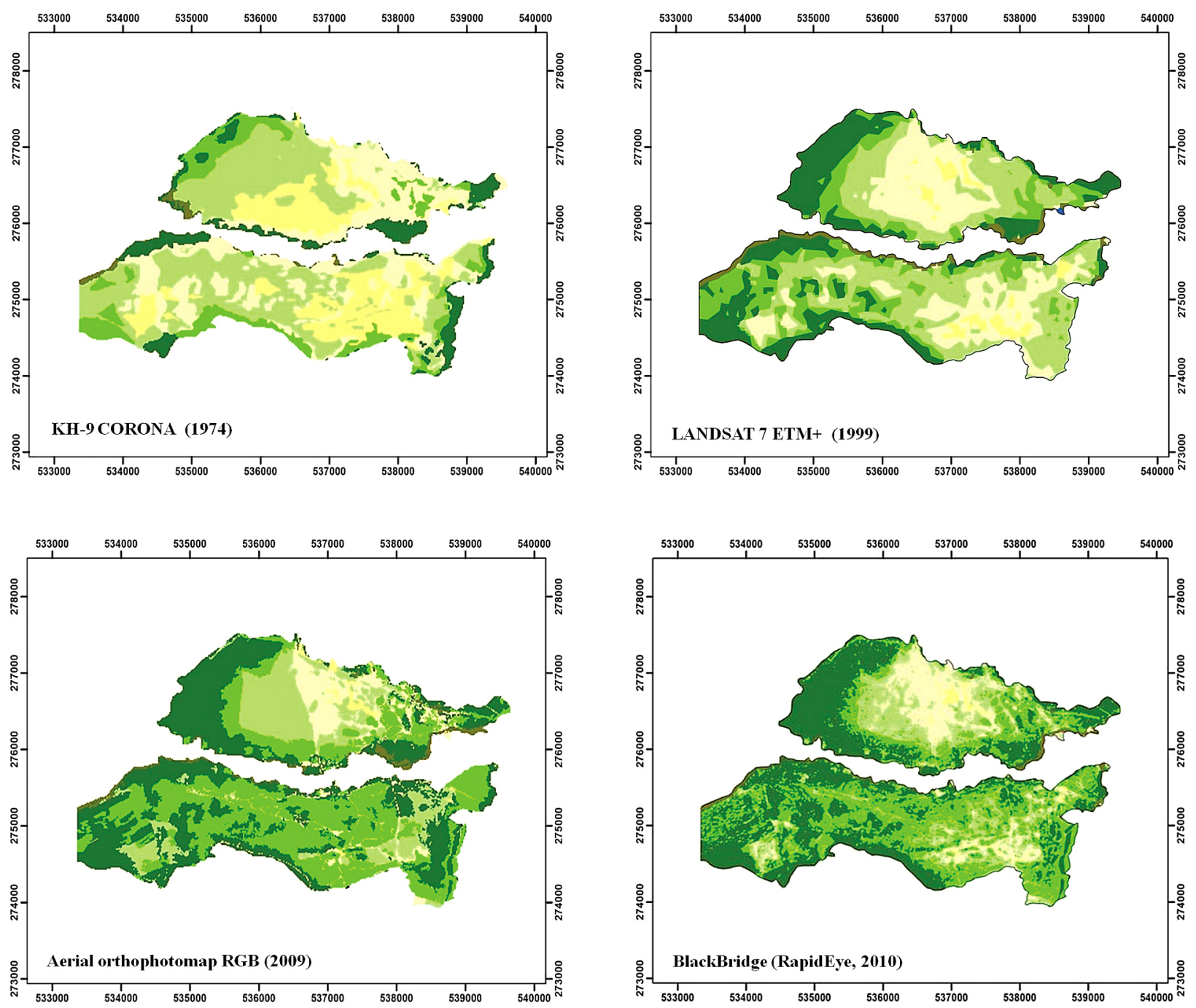

LEGEND:

$\square$ Coniferous forest $\square$ Decidious forest $\square$ Sparse forest $\square$ Bush Bare soil Initial vegetation

Fig. 3. LULC maps of the Błędów Desert. a) KH-9 CORONA (1974), b) LANDSAT 7 ETM+ (1999), c) aerial orthophoptomap (2009), d) BlackBridge (RapidEye, 2010).

Table 1. The distribution of LULC classes in the test area.

\begin{tabular}{|c|c|c|c|c|c|c|c|c|c|c|c|c|}
\hline Method & \multicolumn{8}{|c|}{ Photointerpretation and on-screen vectorization } & \multicolumn{4}{|c|}{ Image classification } \\
\hline \multirow{3}{*}{$\begin{array}{l}\text { Image (Year) } \\
\text { LULC Class }\end{array}$} & \multirow{2}{*}{\multicolumn{2}{|c|}{$\begin{array}{l}\text { KH-9 } \\
\text { (1974) }\end{array}$}} & \multirow{2}{*}{\multicolumn{2}{|c|}{$\begin{array}{c}\text { LANDSAT } 7 \\
\text { (1999) }\end{array}$}} & \multirow{2}{*}{\multicolumn{2}{|c|}{$\begin{array}{c}\text { ORTHO/ } \\
\text { RapidEye } \\
(2009 / 2010)\end{array}$}} & \multicolumn{2}{|c|}{ LULC changes } & \multirow{2}{*}{\multicolumn{2}{|c|}{$\begin{array}{c}\text { RapidEye } \\
\text { GEOBIA } \\
(2010)\end{array}$}} & \multirow{2}{*}{\multicolumn{2}{|c|}{$\begin{array}{c}\text { RapidEye } \\
\text { pixel-bas.cl. } \\
(2010)\end{array}$}} \\
\hline & & & & & & & \multirow{2}{*}{\begin{tabular}{|c|}
1974 \\
$-2009 /$ \\
10 \\
$\%$ \\
\end{tabular}} & \multirow{2}{*}{$\begin{array}{c}1999 \\
-2009 / \\
10 \\
\%\end{array}$} & & & & \\
\hline & [ha] & $\%$ & [ha] & $\%$ & [ha] & $\%$ & & & [ha] & $\%$ & [ha] & $\%$ \\
\hline Coniferous forest & 126.3 & 10.4 & 258.4 & 21.3 & 402.9 & 33.3 & 22.9 & 12.0 & 406.5 & 33.5 & 464.2 & 38.4 \\
\hline Deciduous forest & 14.4 & 1.2 & 35.3 & 2.9 & 28.8 & 2.4 & 1.2 & -0.5 & 41.3 & 3.4 & 22.2 & 1.8 \\
\hline Sparse forest & 187.2 & 15.5 & 206.9 & 17.1 & 468.9 & 38.7 & 23.2 & 21.6 & 390.1 & 32.2 & 369.7 & 30.5 \\
\hline Bush & 369.6 & 30.5 & 398.4 & 32.9 & 191.4 & 15.8 & -14.7 & -17.1 & 203.8 & 16.9 & 215.6 & 17.8 \\
\hline Initial vegetation & 280.0 & 23.1 & 272.8 & 22.5 & 105.5 & 8.7 & -14.4 & -13.8 & 145.0 & 12.0 & 126.8 & 10.5 \\
\hline Bare soil & 233.0 & 19.3 & 38.7 & 3.2 & 13.0 & 1.1 & -18.2 & -2.1 & 23.9 & 2.0 & 12.0 & 1.0 \\
\hline Test area & & & & & & & 10 & & & & & \\
\hline
\end{tabular}




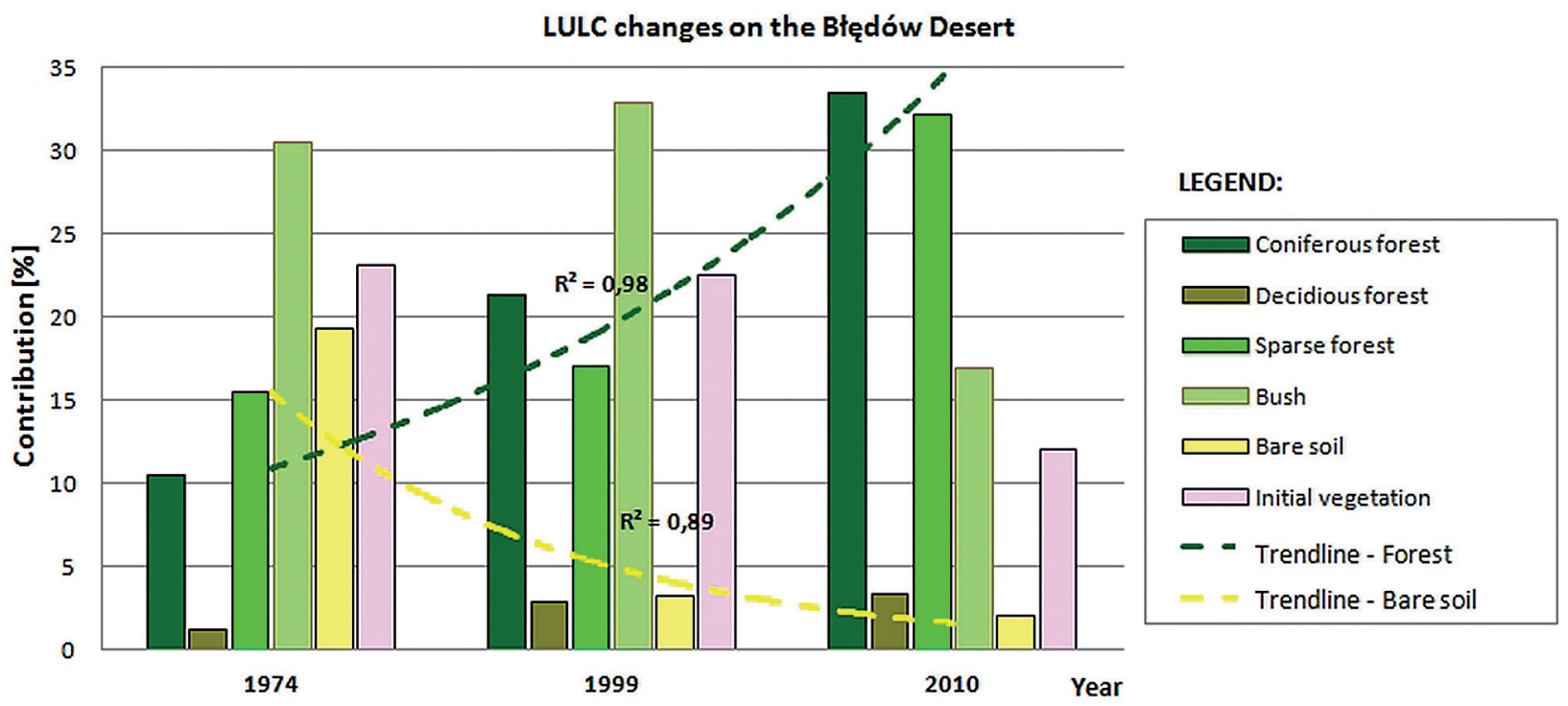

Fig. 4. LULC changes on the Błędów Desert - trend lines.

forest class gathered using on-screen digitizing and witch using the GEOBIA approach. Using the pixel-based classification approach resulted in a 3.3\% difference than that gathered by GEOBIA.

The European Environmental Project Corine Land Cover (CLC, 2006) shows three main LULC classes in the Błędów Desert, i.e.: sparsely vegetated areas (code: 333 ) - $61.3 \%$ of total area, transitional woodland-shrub (code: 324 ) - $22.3 \%$ and coniferous forest (code: 312 ) $-14.3 \%$. Other classes are: mixed forest (code: 313 ) $-1.6 \%$ and broad-leaved forest (code: 311 ) $-0.5 \%$.

This study showed that detecting vegetation classes in an automatic way using the image data is possible by using pixel-based classification or GEOBIA data processing powered by GIS spatial analyses. Due to the similar results obtained compared to the traditional on-screen photointerpretation methods, the achieved results have allowed authors to establish the relevance of the automation of LULC categorization through the application of pixel-based classification (Kappa LANDSAT $7=80 \%$ and KappaRapidEye $=82 \%$ ) or GEOBIA classification (Kappa $=87 \%$ ). Kappa coefficient shows that classification is moderately accurate (Jensen 2005).

\section{Discussion and conclusions}

GI technologies can support field works concerning the active protection and understanding of the transformation of the habitats of the Błędów Desert. Combining the spatial location and data with the time factor enables the monitoring of the dynamic of the changes of different vegetation types. The origin of the Desert is connected with the intensive logging started in the Middle Ages as a result of intensive development of ore industry. Grazing of the uncovered areas and later on the use of the area for military purposes (field training area for Africa Corps troops) was also important in keeping the desert character of the landscape. A long time after the end of the World War II the sandy soils of the Błędów Desert had been an interesting location for military troops as a training area that simulated a desert environment. As a result, it was regularly abused by heavyweight equipment, which adversely affected any potential succession. Since the beginning of 1960s in the area of Desert intensive processes of primary and secondary succession have been observed in the aspect of natural processes as well as anthropogenic processes connected with deliberate introduction of vegetation and forming the protective belt around the Katowice Steelworks. Primary succession was found on the ground almost completely without soil, while secondary, much more common, was noticed on sands, enriched with organic material or in the areas with partially destroyed, relic soil cover (Rahmonov et al. 2006).

In the last years, some protective activities supported by the Life+ projects are carried out on 

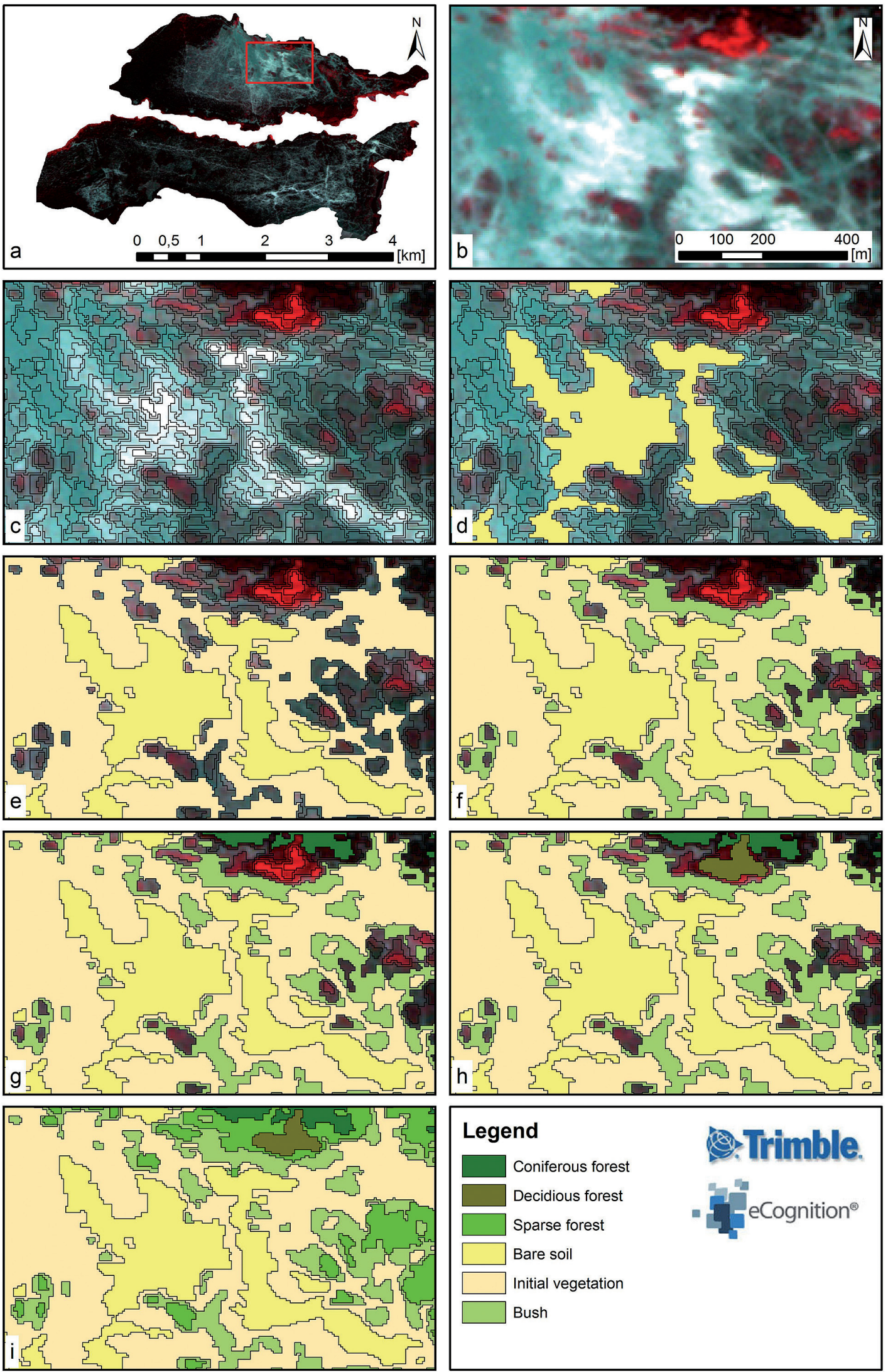

Fig. 5. The steps of the GEOBIA approach: a) an example of AOI (red) processed with OBIA; b) enlarged AOI (Rapid Eye); c) image segmentation (start of GEOBIA); d) bare soil; e) initial vegetation; $\mathrm{f}$ ) bush; $\mathrm{g}$ ) coniferous forests; h) deciduous forests; i) sparse forests (end of GEOBIA). 
the Błędów Desert with the main goal of preserving the very rare dry terrestrial ecosystem. The conservation treatments rely on deterrence of the bush and tree re-growing and keeping clean the sandy bare soil. The scientific topic of overgrowing the Błędów Desert has been investigated by others authors (Bryś, Gołuch 2011, Maryniak, Drzewiecki 2010, Rahmonov et al. 2006, Szczypek et al. 1994). Also in this case, the authors indicate an intensive process of overgrowing the Błędów Desert by shrub vegetation. There is a great similarity in land cover classes of the Błędów Desert (the analysed data from a similar period of time) - the forest succession can be seen. The changes in land cover classes structure are clearly seen in a small time interval.

Based on the results of the presented work, it can be stated, that the geomatics technologies (like GEOBIA, remote sensing etc.) can now replace the manual work of an operator (photointerpretation) in determining the borders of the LULC classes and monitoring process of the secondary forest succession. The geodata and modern technologies provide accurate information on the spatial and temporal distribution of LULC classes and deliver indicators that show the dynamic process of the landscape changes (especially process of the secondary forest succession) including the spatial range and structure of vegetation (Bergen, Dronova 2007, Falkowski et al. 2009, Mancino et al. 2014, Suzanchi, Kaur 2011). The automation of the processing using GIS analysis and GEOBIA tools, allows for the obtainment of very accurate borders of the land cover classes compared to the traditionally applied photo-interpretation and on-screen vectorization methods, but in a faster, more cost-effective, objective and efficient way (Moskal, Jakubauskas 2013, Szostak et al. 2014, Wężyk, de Kok 2005).

It can be concluded, that for many years a high demand for an improvement of the existing LULC databases has been observed. Specifically the pan-European CLC initiative or local (regional or national) mapping. Such data is widely used in many aspects of Earth ecosystem monitoring and management but sometimes they are not detailed enough because of the GSD of the satellite images. The LULC maps are needed for the protection of the habitats, agriculture and forest policy, hydrology modelling (floods), sustainable management of the environment, monitoring of the influence of climate change, etc. As a result of the technical advances in hardware and software systems and a vast amount of remote sensing data available from EO satellites, the demand for precise and up-to-date LULC maps can potentially be satisfied nowadays. Even a new satellite constellation, built-up from dozens of nanosatellites (e.g. Planet Labs) will deliver very soon a TB of imagery data of each piece of the Earth every day (GSD $4 \mathrm{~m}$ ). The highly automated image analysis of huge data sets is possible thanks to modern and efficient methods like GEOBIA and the developed GIS systems based on cloud processing.

\section{References}

Baatz M., Hoffmann C., Willhauck G., 2008. Progressing from Object-Based to Object-Oriented Image Analysis. In: Blaschke T., Lang S., Hay G.J. (eds), Object-Based Image Analysis: Spatial Concepts for Knowledge-Driven Remote Sensing Applications. 1st ed. Springer, Berlin, Heidelberg: 29-42.

Baatz M., Schape A., 2000. Multiresolution Segmentation: An Optimization Approach for High Quality Multi-Scale Image Segmentation. Journal of Photogrammetry and Remote Sensing 58(3-4): 12-23.

Benz U., Hofmann P., Willhauck G., Lingenfelder I., Heynen M., 2004. Multi-Resolution, Object-Oriented Fuzzy Analysis of Remote Sensing Data for GIS-Ready Information. ISPRS Journal of Photogrammetry and Remote Sensing 58(34): 239-258. DOI: 10.1016/j.isprsjprs.2003.10.002.

Bergen K.M., Dronova I., 2007. Observing Succession on Aspen-Dominated Landscapes Using a Remote Sensing-Ecosystem Approach. Landscape Ecology 22(9): 13951410. DOI: $10.1007 /$ s10980-007-9119-1.

Blaschke T., Hay G.J., Kelly M., Lang S., Hofmann P., Addink E., Queiroz Feitosa R. et al., 2014. Geographic Object-Based Image Analysis - Towards a New Paradigm. ISPRS Journal of Photogrammetry and Remote Sensing 87 (January): 180-191. DOI: 10.1016/j.isprsjprs.2013.09.014.

Blaschke T., 2010. Object Based Image Analysis for Remote Sensing. ISPRS Journal of Photogrammetry and Remote Sensing 65(1): 2-16. DOI: 10.1016/j.isprsjprs.2009.06.004.

Bork E.W., Su J.G., 2007. Integrating LIDAR Data and Multispectral Imagery for Enhanced Classification of Rangeland Vegetation: A Meta Analysis. Remote Sensing of Environment 111(1): 11-24. DOI: 10.1016/j.rse.2007.03.011.

Bryś H., Gołuch P., 2011. Pustynia Błędowska dawniej i dziś - interpretacja wieloczasowych zdjęć. Acta Scientiarum Polonorum. Geodesia et Descriptio Terratum 10(2): 5-15.

Coops N., White J.D., 2003. Modeling Forest Productivity Using Data Acquired through Remote Sensing. In: Wulder M., Franklin S.E. (eds), Remote Sensing of Forest Environments: Concepts and Case Studies. Springer: 411-432.

Corona P., Lamonaca A., Chirici G., 2008. Remote Sensing Support for Post Fire Forest Management. Iforest-Biogeosciences and Forestry 1: 6-12. DOI: 10.3832/Ifor03050010006.

Corine Land Cover (http://www.eea.europa.eu/publications/COR0-landcover). 
de Kok R., Wężyk P., 2008. Principles of Full Autonomy in Image Interpretation. The Basic Architectural Design for a Sequential Process with Image Objects. In: Blaschke T., Lang S., Hay G.J. (eds), Object-Based Image Analysis: Spatial Concepts for Knowledge-Driven Remote Sensing Applications. 1st ed. Springer, Berlin, Heidelberg: 697-710.

Drzewiecki W., Wężyk P., Pierzchalski M., Szafrańska B., 2014. Quantitative and Qualitative Assessment of Soil Erosion Risk in Małopolska (Poland), Supported by an Object-Based Analysis of High-Resolution Satellite Images. Pure and Applied Geophysics 171(6): 867-895. DOI: 10.1007/s00024-013-0669-7.

Falkowski M.J., Evans J.S., Martinuzzi S., Gessler P.E., Hudak A.T., 2009. Characterizing Forest Succession with Lidar Data: An Evaluation for the Inland Northwest, USA. Remote Sensing of Environment 113(5): 946-956. DOI: 10.1016/j.rse.2009.01.003.

Hay G.J., Castilla G., 2006. Object-Based Image Analysis: Strengths, Weaknesses, Opportunities and Threats (SWOT). The International Archives of the Photogrammetry, Remote Sensing and Spatial Information Sciences 36: 4.

Hay G.J., Castilla G., 2008. Geographic Object-Based Image Analysis (GEOBIA): A New Name for a New Discipline. In: Blaschke T., Lang S., Hay G.J. (eds), Object-Based Image Analysis: Spatial Concepts for Knowledge-Driven Remote Sensing Applications. 1st ed. Springer, Berlin, Heidelberg: 75-89. DOI: 10.1007/978-3-540-77058-9.

Jensen J.R., 2005. Introductory Digital Image Processing. 3rd ed. Latifi H., Galos B., 2010. Remote Sensing-Supported Vegetation Parameters for Regional Climate Models: A Brief Review. Iforest-Biogeosciences and Forestry 3: 98-101. DOI: 10.3832/ifor0543-003.

Mancino G., Nolè A., Ripullone F., Ferrara A., 2014. Landsat TM Imagery and NDVI Differencing to Detect Vegetation Change: Assessing Natural Forest Expansion in Basilicata, Southern Italy. iForest - Biogeosciences and Forestry 7(2): 75-84. DOI: 10.3832/ifor0909-007.

Maryniak D., Drzewiecki W., 2010. The Błędów Desert Land Cover Change in the Years 1926-2005. Archives of Photogrammetry, Cartography and Remote Sensing 21: 245-256.
Moskal L.M., Jakubauskas M., 2013. Monitoring Post Disturbance Forest Regeneration with Hierarchical Object-Based Image Analysis. Forests 4(4): 808-829. DOI: 10.3390/f4040808.

Rahmonov O., Szczypek T., Wach J., 2006. The Błędów Desert (Pustynia Błędowska) - a unique phenomenon of the Polish landscape. Annales Geographicae 39(1): 34-41.

Singh K.K., Vogler J.B., Shoemaker D.A., Meentemeyer R.K., 2012. LiDAR-Landsat Data Fusion for Large-Area Assessment of Urban Land Cover: Balancing Spatial Resolution, Data Volume and Mapping Accuracy. ISPRS Journal of Photogrammetry and Remote Sensing 74 (November): 110-21. DOI: 10.1016/j.isprsjprs.2012.09.009.

Suzanchi K., Kaur R., 2011. Land Use Land Cover Change in National Capital Region of India: A Remote Sensing \& GIS Based Two Decadal Spatial-Temporal Analyses. Procedia - Social and Behavioral Sciences 21: 212-221. DOI: 10.1016/j.sbspro.2011.07.044.

Szczypek T., Wach J.S.W., 1994. Changes in Btędów Desert Landscapes. WNoZ UŚ: Sosnowiec.

Szostak M., Wężyk P., Tompalski P., 2014. Aerial Orthophoto and Airborne Laser Scanning as Monitoring Tools for Land Cover Dynamics: A Case Study from the Milicz Forest District (Poland). Pure and Applied Geophysics 171(6): 857-866. DOI: 10.1007/s00024-013-0668-8.

Wężyk P., de Kok R., 2005. Automatic Mapping of the Dynamics of Forest Succession on Abandoned Parcels in South Poland. In: Strobl et al. (eds), Angewandte Geoinformatik. Herbert Wichman Verlag, Heidelberg: 774-779.

Wężyk P., Szostak M., Tompalski P., 2013. Use of Airborne Laser Scanning Data for a Revision and Update of a Digital Forest Map and Its Descriptive Database: A Case Study from the Tatra National Park. In: Kozak J., Katarzyna O., Bytnerowicz A., Wyżga B. (eds), The Carpathians: Integrating Nature and Society Towards Sustainability. Springer: 615-627.

Willhauck G., Schneider T., de Kok R., Ammer U., 2000. Comparison of Object Oriented Classification Techniques and Standard Image Analysis for the Use of Change Detection between SPOT Multispectral Satellite Images and Aerial Photos. ISPRS Archives 33 (Supplement B3): 214-221. 